\title{
CATHOLIC TEACHER PREPARATION
}




\title{
Emerald Studies in Teacher Preparation in National and Global Contexts
}

\author{
Series Editors: Teresa O'Doherty \\ Marino Institute of Education, Dublin, Ireland \\ Judith Harford \\ University College Dublin, Ireland \\ Thomas O'Donoghue \\ University of Western Australia, Australia
}

Teacher preparation is currently one of the most pressing and topical issue in the field of education research. It deals with questions such as how teachers are prepared, what the content of their programmes of preparation is, how their effectiveness is assessed, and what the role of the 'good' teacher is in society. These questions are at the forefront of policy agendas around the world.

This series presents robust, critical research studies in the broad field of teacher preparation historically, with attention also being given to current policy and future directions. Most books in the series will focus on an individual country, providing a comprehensive overview of the history of teacher preparation in that country while also making connections between the past and present and informing discussions on possible future directions.

\section{Previously published:}

Teacher Preparation in Ireland: History, Policy and Future Directions By Thomas O'Donoghue, Judith Harford, Teresa O'Doherty

Forthcoming in this series:

Teacher Preparation in Northern Ireland

By Séan Farren, Linda Clarke and Teresa O'Doherty

Teacher Preparation in Australia

By Thomas O'Donoghue and Keith Moore

Historical Development of Teacher Education in Chile By Beatrice Avalos-Bevan and Leonora Reyes-Jedlicki 


\section{CATHOLIC TEACHER PREPARATION}

\section{Historical and Contemporary Perspectives on Preparing for Mission}

BY

RICHARD RYMARZ

BBI - The Australian Institute of

Theological Education, Australia

\section{LEONARDO FRANCHI}

University of Glasgow, UK

\section{emerald PUBLISHING}


Emerald Publishing Limited

Howard House, Wagon Lane, Bingley BD16 1WA, UK

First edition 2019

Copyright (C) 2019 Emerald Publishing Limited.

\section{Reprints and permissions service}

Contact: permissions@emeraldinsight.com

No part of this book may be reproduced, stored in a retrieval system, transmitted in any form or by any means electronic, mechanical, photocopying, recording or otherwise without either the prior written permission of the publisher or a licence permitting restricted copying issued in the UK by The Copyright Licensing Agency and in the USA by The Copyright Clearance Center. Any opinions expressed in the chapters are those of the authors. Whilst Emerald makes every effort to ensure the quality and accuracy of its content, Emerald makes no representation implied or otherwise, as to the chapters' suitability and application and disclaims any warranties, express or implied, to their use.

\section{British Library Cataloguing in Publication Data}

A catalogue record for this book is available from the British Library

ISBN: 978-1-78756-007-9 (Print)

ISBN: 978-1-78756-006-2 (Online)

ISBN: 978-1-78756-008-6 (EPub)

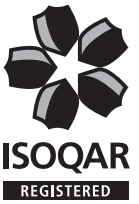

ISOQAR certified

Management System,

awarded to Emerald

for adherence to

Environmental

standard

ISO 14001:2004. 


\section{Contents}

\section{Introduction}

I.1. Rationale

I.2. Research Approach 5

I.3. Chapter Summaries 6

I.4. Notes on Referencing 8

\section{PART I}

Chapter 1 Exploring Catholic Education 11

1.1. Catholic Teacher Preparation: Theological Themes 11

1.1.1. A Catholic Understanding of the Human Person: Catechism of the Catholic Church 14

1.1.2. A Catholic Understanding of the Human Person: Educational Implications 15

1.1.3. The Relationship between Faith and Reason: Catechism of the Catholic Church 15

1.1.4. The Relationship between Faith and Reason: Educational Implications 15

1.1.5. The Importance of Ritual: Catechism of the Catholic Church

1.1.6. The Importance of Ritual: Educational Implications 16

1.2. Contemporary Church Teaching on Education 16

1.3. The Work of the Congregation of Catholic Education: Summary of Themes 18

Chapter 2 Teacher Preparation: Insights from History 21

2.1. Four Historical Themes 21

2.1.1. Theme 1: An Emerging Philosophy of Catholic Education

2.1.2. Theme 2: Developing a Sense of Pastoral Care 23

2.1.3. Theme 3: Education as an Act of Reason 25

2.1.4. Theme 4: A Humanistic Education 27

2.2. The Council of Trent and the Society of Jesus:

Developing Teacher Preparation 30

2.3. Concluding Remarks 33 
Chapter 3 The Rise of the Teaching Congregations

3.1. Teacher Preparation and Religious Life

3.2. Jean-Baptiste De La Salle: The Brothers of the Christian Schools

3.2.1. De La Salle in the History of Education

3.2.2. De La Salle and Teacher Preparation: Seeking Integral Formation

41

3.2.3. De La Salle: Concluding Remarks

3.3. Sr Julie Marie Billiart: The Sisters of Notre Dame de Namur

3.3.1. Forming a Community of Educators

3.3.2. Julie Marie Billiart - The 'Quiet Revolutionary' 46

3.3.3. Sisters of Notre Dame: Concluding Remarks 50

3.4. Concluding Remarks

\section{Chapter 4 A New World: Expansion and Growth in a} Secular Society, the Decline of the Teaching Orders and the Emergence of Lay Teachers

4.1. Catholicism and Education: From Industrialisation to the Second Vatican Council

4.2. Catholic Education, the Second Vatican Council and the Congregation for Catholic Education

4.2.1. The Catholic School, $1977 \quad 58$

4.2.2. Lay Catholics in Schools: Witnesses to Faith, $1982 \quad 58$

4.2.3. The Religious Dimension of Education in a Catholic School, 1988

4.2.4. The Catholic School on the Threshold of the Third Millennium, 1977

4.2.5. Consecrated Persons and Their Mission in Schools: Reflections and Guidelines, 2002

4.2.6. Educating Together in Catholic Schools: A Shared Mission between Consecrated Persons and the Lay Faithful, 2007

4.2.7. Circular Letter to Presidents of Bishops' Conferences on Religious Education in Schools, 2009

4.2.8. Educating to Intercultural Dialogue in Catholic Schools: Living in Harmony for a Civilisation of Love, 2013

4.2.9. Educating to Fraternal Humanism: Building a 'Civilization of Love' 50 Years afterPopolorum Progressio, 2017 
4.3. Discussion

4.4. Catholic Teacher Preparation: The Mind of the Congregation for Catholic Education

4.4.1. Theme 1: Where Catholic Teacher Preparation Takes Place

4.4.2. Theme 2: Developing Knowledge and Expertise: The Professional Identity of the Teacher 68

4.5. Concluding Thoughts

\section{PART II}

Chapter 5 Catholic Teacher Preparation around the Globe: Four International Case Studies

5.1. New Zealand 73

5.2. Canada 76

5.3. Australia 79

5.4. Scotland 82

5.5. Discussion 84

Chapter 6 The Contemporary Landscape: Parents' Expectations for Catholic Schools and Some Implications for Teacher Preparation

6.1. Parental Choice in School Selection: An Overview

6.2. Setting a Theoretical Context: Religious-Secular Competition

6.3. Methodology

6.4. Results and Discussion

Chapter 7 Teacher Preparation: A Focus on Religious Education 101

7.1. Content Knowledge and the RE Teacher in Catholic Schools: The General Case

Chapter 8 At the Coalface: Vignettes of Young Teachers in

8.1. Introduction

8.2. Kathy: So Happy to Be Here

8.3. Tobias: A Reconnecting Narrative

8.4. Amy: Home is Always Home

8.5. Carmela: Doing My Bit

8.6. Mathilde: Called to Teach

8.7. Joshua: A non-Catholic Teacher

8.8. Conclusion 
Chapter 9 Taking a Closer Look at Young Teachers in Catholic Schools: An Empirical Investigation of Some Issues and Challenges 113 9.1. Introduction

9.2. Methodology

9.3. Results

9.3.1. Generational Issues

9.3.2. Experience of the School

9.3.3. Teaching Religious Education

9.3.4. Aspects of Worldview

9.3.5. Networks

9.3.6. Support

9.4. Conclusion

Chapter 10 The Way Forward: Reflecting on the Future of Catholic Teacher Preparation

10.1. Formation and Teaching Religious Education

10.1.1. Shifting the Paradigm and the Expectations 128

10.1.2. Meeting the High Bar

10.2. Teacher Preparation: Some Challenges and Metaphors

Afterword

Appendix 1 - Catholic Teacher Preparation: Learning from the Gospels

Appendix 2 - Catholic Teacher Preparation: Magisterial

Documents

References

Index 


\section{Introduction}

We begin with a rationale for the study of Catholic teacher preparation. This is followed by an overview of our research approach and chapter summaries.

\section{I.1. Rationale}

It is, of course, a truism that good schools need good teachers - and, by implication, good teacher preparation processes. In an encomium on the value of Catholic education in the USA at the turn of the twentieth century, J. A. Burns, drawing on the Third Council of Baltimore in 1884, noted that the quality of education provided in a school is in proportion to the quality of 'training' received by the teacher. ${ }^{1}$ Who would reasonably argue today with such a comment?

Catholic teacher preparation, the subject of this book, refers to the combination of academic and pastoral processes which offer students a recognised qualification to teach in Catholic schools. It is thus an essential strand in the fabric of Catholic education.

Catholic schools are a component part of many national school systems. ${ }^{2}$ Each national system, so to speak, of Catholic education operates in the midst of relationships, both smooth and fraught, with the educational agencies of the state. This highly-charged context militates against the drawing of firm and universally applicable conclusions about the effectiveness and culture of such schools.

What is the essence of Catholic education? St Anselm's classic definition of theology as 'faith seeking understanding' is, to be sure, a statement of profound importance for educators. Such a commitment to 'seeking' implies that truth awaits us. Education from a Catholic perspective is, hence, the seeking to understand multiple issues, not least the perennial questions regarding the ultimate foundations of life. ${ }^{3}$ It is an invitation to take part in a lifelong search for

\footnotetext{
${ }^{1}$ J. A. Burns, 'The training of the teacher', American Catholic Quarterly, Vol. 28, 1903, pp. 665-683.

${ }^{2}$ G. Grace \& J. O'Keefe (Eds.), International Handbook of Catholic Education: Challenges for School Systems in the $21^{\text {st }}$ Century Part 1 (Dordrecht: Springer, 2007).

${ }^{36}$ Faith seeking understanding' is the 'motto' of St Anselm of Canterbury (1033-1109). See this overview of his life and work from the Stanford Encyclopedia of Philosophy: https://plato.stanford.edu/entries/anselm/\#FaiSeeUndChaPurAnsThePro
} 
meaning, supported along the way by the pillars of prayer, study, dialogue and reflection.

As products of many styles of education, formal and informal, in the home, school, college and university, it is perhaps inevitable that we are prey to viewing contemporary educational developments through the lenses of our own experiences. Progressing through life, we take up roles which, implicitly or explicitly, require us to guide, counsel and instruct others in multiform tasks. Some of these are practical (repairing a puncture on a bike) or more formational (giving advice on career choices). It might require the passing on of guidance which we ourselves have imbibed from others or, possibly, demand substantial intellectual digging on our part before we feel confident enough to play the role of mentor, counsellor and coach.

Despite this tendency to focus on the personal, it is also clear that the 'history of education' offers a vast panorama for study. There are so many possible avenues therein that it can be quite hard to know where to begin the scholarly journey. For the purpose of the present volume, we recognise that 'teacher preparation' as a distinctive educational phenomenon is part of the move towards so-called mass education in the nineteenth century. This epoch afforded the Catholic Church a valuable opportunity to draw on its own distinguished educational history for further inspiration on how best to develop its growing number of schools, and doing so in line with the raised expectations placed on schools more generally. The commitment to expansion required a similar commitment to the construction of suitable models of teacher preparation and, hence, it is reasonable to talk about Catholic teacher preparation as a field of study in its own right.

What makes a good teacher? Is it possible to devise a template of what this person 'looks like'? Indeed, should we even be thinking that good teachers emerge from pre-set moulds? Yet this attention to formula is very much part of the contemporary educational climate. Higher education, for example, promotes the concept of 'graduate attributes', a pre-determined sketch of the professional and personal attributes which, allegedly, differentiate graduates from the rest of the population. ${ }^{4}$ This is a close relative of the schema of professional competences which are designed to mark progression through different stages of the career of a teacher.

Of course, a skilled and proficient teacher, no matter the immediate working context, will encourage students to engage meaningfully with the curriculum. To be clear, the good teacher will teach students to use the skills of reflections and critical enquiry to develop an ethical and 'wisdom-driven' response to inherited

\footnotetext{
${ }^{4}$ The UK-based Higher Education Academy offers an overview of 'graduate attributes' which it summarises as follows 'components which relate to the mastery of subject-specific knowledge, study skills, digital literacies and other 21 st century skills' (https://www.heacademy.ac.uk/knowledge-hub/graduate-attributes-framework).
} 
knowledge. ${ }^{5}$ This way of acting is far removed from an unsophisticated attachment to 'constructivism' which often underpins self-proclaimed 'modern' educational practice. ${ }^{6}$

Debates on how to develop teacher preparation must recognise the important role played by the group known as 'teacher educators', sometimes described as the 'hidden professionals' in the system and who, for the most part, are part of Tertiary education. ${ }^{7}$ Teacher preparation, however, takes places on a number of sites, not just in the university. The school is often seen as a key place for teacher preparation. This leads to another important question: is the school or the institution of higher education the principal provider? If the former, are class teachers sufficiently well-versed in the broader academic theories necessary to provide a scholarly underpinning to the process; if the latter, are academics, even if former classroom teachers, too far removed from classroom life to offer anything but advice from memory to aspirant teachers? We suggest that those working in the field of teacher preparation are required to achieve levels of scholarship commensurate with the expectations of academics in other fields alongside an appreciation of the perceived practical wisdom which is an indispensable part of the life of the school. The bar is, and should be, high.

It is also vital to focus on the educational experience offered to students of education in recognition of their double-identity as both 'students' and 'teachers'. A fortiori institutions where formal teacher preparation takes place, as well as dealing comprehensively with the many and profound educational implications of the so-called knowledge/skills debate which continue to have an impact on education, must also grapple with the relationship between the life of the school and the nature of the teacher preparation programmes studied in the tertiary institutions.

A sharp separation of skills and knowledge in educational discourse is, potentially, a barrier to rounded debate on the aims and purposes of the mission of education. Skills, be they intellectual or practical, are part of a process of knowledge communication. A skilled teacher allows students to engage meaningfully with multiple bodies of knowledge, encouraging an ethical and coherent response to what has been learnt and, where appropriate, offering practical opportunities for the application of knowledge. For example, should teacher preparation be explicitly linked to national school curricula - and hence be deemed professionally

\footnotetext{
${ }^{5} \mathrm{G}$. Biesta, 'The future of teacher education: Evidence, competence or wisdom', Research on Steiner Education (ROSE), Vol. 3, No. 1, 2009, pp. 8-21.

${ }^{6} \mathrm{P}$. Kirschner, P. Sweller, and R. Clark, 'Why minimal guidance during instruction does not work: An analysis of the failure of constructivist, discovery, problem-based, experiential, inquiry-based teaching', Educational Psychologist, Vol. 41, No. 2, 2006, pp. 75-86.

${ }^{7}$ K. Livingstone, ' Teacher educators: Hidden professionals?' European Journal of Teacher Education, Vol. 49, No. 2, 2014, pp. 218-232.

${ }^{8}$ F Caena, Initial Teacher Education in Europe: An Overview of Policy Issues. Brussels: European Commission, 2014.
} 
'relevant' - or should it take the form of a more liberal programme of studies which aims principally at wider intellectual formation of the students?

To move this debate forward, a nuanced appreciation of the relationship between 'training' and 'education' in teacher preparation programmes is crucial. Sometimes this relationship is set out in a binary way: are we offering students an opportunity to learn a set of skills and techniques which will be helpful in the classroom situation or should we be offering our students an opportunity to engage with a broad range of educational ideas. Richard Pring's fourfold schema of ways of 'doing' teacher preparation offers a helpful point of orientation:

(1) no need for professional training, only subject knowledge gained in university studies;

(2) professional training in addition to subject knowledge but with the training undertaken elsewhere (school or in a professional centre);

(3) balance of professional training between initial and later periods of a teaching career should be balanced in favour of the latter; and

(4) professional training should have a strong theoretical/research base so it should be the responsibility of the university, perhaps in partnership with schools. There are many ways in which this could be done. ${ }^{10}$

This is a clear outline of possibilities, applicable to prospective teachers for all types of schools. When applied to teachers for Catholic schools, there are added layers: (1) the faith formation of the teacher as a 'professional' requirement and (2) alignment with the educational priorities of the local/universal Church.

We would be loath to recommend any one position from Pring's schema as the ideal expression of the Catholic intellectual tradition, understood here as the Church's ongoing engagement with the world of ideas: from Blessed John Henry Newman's encomium on the value of a liberal education to John Baptiste de La Salle's commitment to offering practical guidance for young men selected to teach in schools, the Catholic intellectual tradition is especially pertinent to the development of the Catholic educational mission. ${ }^{11}$

Catholic teacher preparation had traditionally been a mission entrusted to religious Sisters and Brothers. This is no longer the case. The shift from predominance of personnel from religious orders to the increasing presence of lay people

\footnotetext{
${ }^{9}$ L. Franchi, 'Initial Teacher Education in the University (My Little Ship, how Ill-Laden You Are)', European Journal of Teacher Education, Vol. 39, No. 2, 2016, pp. 147-158.

${ }^{10} \mathrm{R}$. Pring, 'Teacher education at Oxford University: James is alive but living in Karachi', in D. Philips, (Ed.) Teacher Education, the University and the Schools (London: Routledge, 2010), pp. 55-63.

${ }^{11}$ P. McQuillan, M. J. James, and T. P. Muldoon, 'A vision for Catholic higher education in the 21st Century: Reflecting on the Boston College roundtable', Journal of Catholic Education, Vol. 21, No. 2, 2018, pp. 107-132 and R. Royal, A Deeper Vision: The Catholic Intellectual Tradition in the Twentieth Century (San Francisco: Ignatius Press, 2015).
} 
is a significant feature of the contemporary Catholic educational landscape. Academic work on the influence of religious orders and teaching congregations on education is an increasingly fertile field but there remains much more to be done specifically on how such institutions can prepare both lay and professed for the mission of Catholic education today.

\section{I.2. Research Approach}

To undertake systematic research in educational matters is akin to swimming in a pleasantly warm yet murky sea. Its connectedness to wider cultural, political and religious developments often makes it a forlorn task to enclose the study of education in a series of airtight boxes. Rather, educational studies, broadly understood, is both intense and interdisciplinary, seeing what 'happens' in our educational institutions as much more than the simple product of teacher-pupil interaction but as an amalgam of multiple, often competing, cultural dynamics.

Educational researchers, following St Anselm, are called to seek truth. The good fruits of educational research findings, however, should not be the plaything of small teams of specialists but must influence policy and be made widely available to the teaching profession. ${ }^{12}$ The importance of the present series of volumes on teacher preparation is that it offers an accessible platform for informed thinking about how teacher preparation has evolved in a wide range of international contexts.

Educational researchers have the luxury of a deep pool from which to draw, from official narratives of developments in public policy documents to personal memoirs of a whole range of educators. Nonetheless, some refinement of method is necessary in order to provide a cohesive, lucid and meaningful narrative for selected audiences.

Serious exploration of Catholic educational institutions cannot ignore the sociological challenges facing the Church, especially in the political systems known collectively (if imperfectly) as the West where the fabric of Catholic life has been seriously weakened by a host of cultural influences and profound educational challenges. ${ }^{13}$ To what extent that is true in particular circumstances can and should be debated but it would seem that the diminution of a (perceived) integrated Catholic culture, one shared between home, parish and school, has been a factor in diminishing the desire of younger Catholics to see teaching as a worthy choice of profession. ${ }^{14}$

\footnotetext{
${ }^{12}$ A. Reid, M. Peters, and P. Hart (Eds.) A Companion to Research in Teacher Education (New York, NY: Springer, 2014).

${ }^{13}$ Pope Benedict XVI, To the Faithful of the Diocese and City of Rome on the Urgent Task of Educating Young People, 2008: https://w2.vatican.va/content/benedict-xvi/en/ letters/2008/documents/hf_ben-xvi_let_20080121_educazione.html

${ }^{14}$ L. Franchi and R. Rymarz, 'The education and formation of teachers for Catholic schools: Responding to changed cultural contexts', International Studies in Catholic Education, Vol. 9, No. 1, 2017, pp. 2-16.
} 
It is important, at this stage, to be clear about the terminology used to describe the different Church groupings involved in the mission of Catholic education.

While the vast majority of the baptised are lay people, the small numbers committed to the priesthood and religious life have traditionally played a disproportionate role in the life of the Church and its educational institutions. Hence it can be easily forgotten that in Catholic thinking, parents are deemed the primary educators of their children, not least in matters of faith formation. Nonetheless, the involvement of the Church in the building of educational establishments is a reminder, as Pope Pius IX noted in 1929, that the family is 'an imperfect society, since it has not in itself all the means for its own complete development'. ${ }^{15}$ In this important, if poorly received line of thinking, civil society seems to precede the family in the search for the common good. The Church is, for Pope Pius IX, 'a perfect society, because it has in itself all the means required for its own end, which is the eternal salvation of mankind, hence it is supreme in its own domain. ${ }^{16}$ This high-powered language, rooted, it seems, in a heavily institutionalized model of Church, is not well aligned with other ecclesiological positions which were recovered and made part of Catholic intellectual life in the late nineteenth and twentieth century. ${ }^{17}$

The words of Pope Pius XI sum up the 'rationale' for Catholic education which had been evident in the rise of religious orders/teaching congregations since the years of the Catholic Reform, starting in the sixteenth century. The use of the term religious orders/congregations reminds us that bodies of professed Christians who were not all priests were the main players in the rise of Catholic educational establishments.

\section{I.3. Chapter Summaries}

Chapter 1 is a broad introduction to the concept of Catholic education. It looks at its principal theological themes and introduces the work of the Congregation for Catholic Education as a backdrop to the study of how teachers are prepared for mission in Catholic schools today.

Chapter 2 presents four historical themes. Each is represented by one significant thinker: St Augustine of Hippo, St Benedict of Nursia, St Thomas Aquinas and Erasmus of Rotterdam. The chapter also explores the influence of the Council of Trent on teacher preparation.

\footnotetext{
${ }^{15}$ Pope Pius XI, Divini Illius Magistri - On Christian Education, 1929, p. 12.

${ }^{16}$ Ibid., p. 13.

${ }^{17}$ We note in particular the recognition of the Church as mystical body of Church, people of God and Communio. There is a wealth of material available for those who wish to deepen their study of the important ecclesiological developments which came to prominence in the twentieth century. See, for example, H. de Lubac, The Splendor of the Church (San Francisco, CA: Ignatius Press, 1956/1986).
} 
Chapter 3 has a focus on the rise of the teaching congregations, with a particular emphasis on the influence of St John Baptise de La Salle's Brothers of the Christian School (De La Salle Brothers) and St Julie Marie Billiart's Sisters of Notre Dame de Namur.

Chapter 4 considers how the Church refreshed its educational mission in the years during and after the Second Vatican Council (1962-1965). The new challenges facing the Church at this time required a re-appraisal of how to present the mission of Catholic education in a time of flux.

Chapter 5 provides an overview of teacher preparation process in four Anglophone domains: Australia, Scotland, Canada and New Zealand. This allows for focussed discussion on common themes and challenges arising in multiple contexts.

Chapter 6 presents empirical data on the important topic of parental choice in education and what this means for Catholic schools in an era when it seems that religious practice as traditionally understood is in decline. This has implications for teachers as the public face of the Church.

Chapter 7 has a focus on content knowledge with particular attention on the expectations the Church has for the subject of religious education. This does not sideline the other subject areas but does stress the centrality of religious education to the mission of the school.

Chapter 8 offers a voice to a diverse range of young teachers in Catholic schools. These six vignettes offer a solid and helpful indication of the realities of teaching in Catholic schools today and make an important claim for inter-generational dialogue.

Chapter 9 elaborates on the work of Chapter 8. It offers the results of an empirical study of teachers in Catholic schools in Australia under the age of 35. The focus of the investigation is worldview, experience and support for teachers.

Chapter 10 brings together the key themes presented in Chapters 5-9. It examines teacher preparation for religious education teachers and sets this in the wider context of the challenges faced by Catholic education today.

Chapter 11 offers a brief summary of the direction of travel of the volume and offers some signposts for reform.

Appendix 1 identifies how teacher preparation can find inspiration in the Gospels.

Appendix 2 sets out the primary texts from Church documents on teacher preparation. 
8 Catholic Teacher Preparation

\section{I.4. Notes on Referencing}

We have followed standard footnote referencing throughout the text. Please note that the full text of references made to Church documents, papal texts and the Catechism of the Catholic Church (CCC) are all available on www.vatican.va. 